\title{
Daily Weather Conditions and Anticipated Death from Cancer
}

\section{In Cheol Hwang ${ }^{1}$ and Hee Kyung Ahn²}

${ }^{1}$ Department of Family Medicine; 2Division of Medical Oncology, Department of Internal Medicine, Gachon University Gil Medical Center, Incheon, Republic of Korea

\section{OBJECTIVE}

The effect of weather conditions on human health has been doc umented. However, the role of daily weather on anticipated deat $\mathrm{h}$ remains unclear. This study aimed to evaluate the relationship between daily weather conditions and death in terminally ill can cer patients.

\section{METHOD}

We retrospectively searched a medical database of 935 consecu tive terminally ill cancer patients who passed away in the palliati ve care unit from Oct 2009 to Sep 2013. We used Poisson regre ssion to assess the relative risk of anticipated death based on va rious weather variables, using mean values calculated from the $10 \mathrm{~d}$ around the time of death.

\section{INTERPRETATION}

- Cold weather induces vasoconstriction and increases blood pressure via stimulation of the sympathetic nervous system. Low temperature also promotes thrombosis by increasing plasma clotting factor concentration and blood viscosity.

- The negative association between sunshine and cancer death could be related to the role that sunshine plays in serotonin production. Sunshine stimulates the production of serotonin by the brain, and serotonin levels in the brain increase significantly during the process of dying.

\section{CONCLUSION}

Weather conditions may be a predictor of death in terminally ill cancer patients.

\section{RESULTS}

\section{Characteristics of participants}

\begin{tabular}{|c|c|}
\hline & No. $(\%)$ \\
\hline Number & 745 \\
\hline Age (years), mean $\pm S D$ & $65.9 \pm 12.2$ \\
\hline Female & $308(41.3)$ \\
\hline \multicolumn{2}{|l|}{ Cancer site } \\
\hline Gastrointestinal & $175(23.5)$ \\
\hline Hepatobiliary & $199(26.7)$ \\
\hline Lung & $189(25.4)$ \\
\hline Genitourinary & $85(11.4)$ \\
\hline Othera & $97(13.0)$ \\
\hline PPI score ${ }^{b}$, mean $\pm S D$ & $8.0 \pm 3.8$ \\
\hline \multicolumn{2}{|l|}{ Seasonal deaths } \\
\hline Spring & $246(33.0)$ \\
\hline Summer & $82(11.0)$ \\
\hline Fall & $189(25.4)$ \\
\hline Winter & $228(30.6)$ \\
\hline \multicolumn{2}{|c|}{ Weather conditions at the day of death } \\
\hline \multicolumn{2}{|l|}{ Temperature } \\
\hline$<$ average $_{10}$ & $373(50.1)$ \\
\hline$\geq$ average $_{10}$ & $372(49.9)$ \\
\hline \multicolumn{2}{|c|}{ Diurnal temperature range } \\
\hline$<$ average $_{10}$ & $370(49.7)$ \\
\hline$\geq$ average $_{10}$ & $375(50.3)$ \\
\hline \multicolumn{2}{|l|}{ Humidity } \\
\hline$<$ average $_{10}$ & $345(46.3)$ \\
\hline$\geq$ average $_{10}$ & $400(53.7)$ \\
\hline \multicolumn{2}{|l|}{ Sunshine } \\
\hline$<$ average $_{10}$ & $312(41.9)$ \\
\hline$\geq$ average $_{10}$ & $433(58.1)$ \\
\hline
\end{tabular}

Relative risk ${ }^{c}$ of death associated with various weather characteristics

\begin{tabular}{|c|c|c|c|c|c|}
\hline & & Unadjusted & & Adjusted & \\
\hline Weather conditiond & No. & $\operatorname{RR}(95 \% \mathrm{Cl})$ & $\mathrm{P}$ & $\mathrm{RR}(95 \% \mathrm{Cl})$ & $P$ \\
\hline Low temperature & 373 & $1.97(1.65$ to 2.36$)$ & $<0.0001$ & $2.17(1.48$ to 3.18$)$ & 0.0001 \\
\hline Large diurnal temperature & 375 & $2.05(1.71$ to 2.45$)$ & $<0.0001$ & $2.53(1.74$ to 3.70$)$ & $<0.0001$ \\
\hline Low humidity & 345 & $1.89(1.58$ to 2.28$)$ & $<0.0001$ & $2.20(1.52$ to 3.20$)$ & $<0.0001$ \\
\hline Much sunshine & 433 & $1.60(1.32$ to 1.93$)$ & $<0.0001$ & $1.83(1.27$ to 2.64$)$ & 0.0012 \\
\hline
\end{tabular}

SD, standard deviation; PPI, palliative prognostic index; $\mathrm{RR}$, relative risk; $\mathrm{Cl}$, confidence interval.

Average $_{10}$ refers to a mean value of 10 days near death.

alncludes breast cancer, hematologic malignancies, etc.

${ }^{\mathrm{b}}$ From last week of life.

'Derived from Poisson regression models with or without adjusting for age, sex, cancer type, and the last palliative prognostic index score. dBased on the mean value of 10 days near death. 